УДК 373.091:811(4)

DOI:

Галина Кемінь, кандидат педагогічних наук, доцент кафедри мовної та міжкультурної комунікації Дрогобицького державного педагогічного університету імені Івана Франка

\title{
ОРГАНІЗАЦІЯ НАВЧАННЯ ІНОЗЕМНОЇ ТА РІДНОЇ МОВИ У “НОВИХ ШКОЛАХ” ЗАХІДНОСВРОПЕЙСЬКИХ КРАЇН
}

У статті проаналізовано організаиійні аспекти навчання іноземної та рідної мови у "нових школах" західноєвропейських крайн. Охарактеризовано методи та прийоми ефективного навчання іноземної та рідної мови, зокрема че читання художніх творів; усне і письмове відтворення прочитаного, побаченого, почутого та пережитого дітьми; ведення щяоденників. Виявлено особисті та професійні якості учителів іноземної мови. Доведено, що організачія навчання у “нових школах” сприяла вихованню всебічно розвиненої ініціативної особистості, яка уміла практично використовувати здобуті знання та самостійно приймати рішення. Вказано на шляхи успішного використання методів навчання “нової школи” у сучасній педагогічній науці та навчально-виховній практиці.

Ключові слова: “нова школа”, навчання, іноземна мова, рідна мова, вчитель, дитина.

Jim. 5.

Halyna Kemin, Ph.D. (Pedagogy), Associate Professor of the Linguistic and Intercultural Communication Department Drohobych Ivan Franko State Pedagogical University

\section{ORGANIZATION OF STUDY OF FOREIGN AND NATIVE LANGUAGES AT "NEW SCHOOLS" IN WEST EUROPEAN COUNTRIES}

The article deals with the organization of study of foreign and native languages in West European countries. Methods and ways of effective study of foreign and native languages are described here. They are as follows: reading literature, oral and written reproductions, keeping diaries.

At "new schools" writing tasks were chosen according to the children's interests. Pupils did them with pleasure. Teachers didn't explain grammar rules to their pupils. Children practiced languages and assured the knowledge and skills necessary for grammar themselves. The teachers of foreign languages were native speakers. They lived, studied or worked abroad. Foreign language teachers spoke foreign languages everywhere, either in classes or in the streets. As soon as children mastered some phrases, they started to write texts on different topics. Senior students kept foreign language diaries. Children didn't learn anything by heart. They didn't study grammar. "New schools" practiced students' exchange within families of different nationalities. According to the curriculum "new schools" were like grammar schools. The teachers'attention was concentrated on the children's interests, their individual needs, positive psychological conditions for the pupils' natural developments, free activities at school and in classes. Teachers were their partners, guardians and tutors. They inspired pupils for freedom, justice and active life in the society.

It has been proved that the aim of study at "new schools" was to develop the children's personality, independence, freedom, activity and art taste. The ways of using the experience of the organization of the educational process in modern pedagogical science and education practice are pointed out in the article.

Keywords: "new school", study, foreign language, native language, a teacher, a child, development, amateur activities.

A ктуальність проблеми. Рух за "нове виховання” у міжвоєнний період набув статусу міжнародного педагогічного руху за оновлення школи й виховання. Авторитарному впливові на дитину протиставлявся процес саморозвитку особистості; навчанню винятково за книжками - навчання через індивідуальний, життєво важливий досвід; суворій дисципліні - вільна внутрішня активність; засвоєнню окремих умінь та навичок шляхом механічного заучування - оволодіння ними в ході виконання самостійної діяльності; підготовці до майбутнього життя - організація активної життєдіяльності. Саме виховання вільної, самостійної, творчої, комунікативної особистості є метою сучасної освіти в Україні. Досвід організації навчання іноземної та рідної мови у “нових школах” зарубіжних країн дає можливість для ефективного використання цих ідей у шкільній практиці.

Аналіз останніх досліджень і публікацій. Дослідження проблем теоретичних основ, змісту, форм організації навчально-виховного процесу у “нових школах” присвячені праці О. Герета, О. Готліба, О. Пінкевич, Г. Поляк, М. Познанського. Деякі аспекти діяльності “нових шкіл” та 


\section{ОРГАНІЗАЦІЯ НАВЧАННЯ ІНОЗЕМНОЇ ТА РІДНОЇ МОВИ У “НОВИХ ШКОЛАХ" ЗАХІДНОЄВРОПЕЙСЬКИХ КРАЇН}

педагогічні погляди їх теоретиків у контексті розвитку реформаторської педагогіки та впровадження у ії̈ зміст гуманістичних концепцій досліджувалися упродовж останнього десятиріччя такими вітчизняними педагогами, якП. Автомонов, П. Браїловська, О. Коваленко, В. Лук'янова, О. Перетятько, В. Петрова, І. Прокоп, І. Суржикова. Однак проблема навчання іноземної та рідної мови у“нових школах” західноєвропейських країн потребує глибшого вивчення 3 метою впровадження досвіду організації навчання в практику сучасної вітчизняної школи.

Метою статті $\epsilon$ проаналізувати зміст та методи навчання іноземної та рідної мови в “нових школах" західноєвропейських країн з метою їх використання у сучасній педагогічній науці та навчально-виховній практиці.

Виклад основного матеріалу. Проблема розумового виховання для “нових шкіл” вважалася стрижневою, адже саме через формування наукового світогляду педагоги “нових шкіл” прагнули активізувати знання своїх вихованців про навколишній світ. Якщо стара школа більше турбувалася про те, щоб озброїти учнів значним багажем фактичних знань, інколи зовсім непридатних до життя, то “нова школа", навпаки, ставила перед собою завдання викликати у дітей любов до наукових занять та навчити їх самостійно думати і працювати. Вважалося, що якщо діти самі будуть жадібно шукати та засвоювати фактичні знання, то вчителю необхідно буде тільки готувати матеріал та допомагати їм розібратися у його розумінні. При такій системі у школах нового типу не було важливим, чи запам'ятав учень якісь факти, чи ні, важливим було, щоб він у випадку необхідності сам зумів їх знайти та орієнтуватися в них. Однак це не означало, що “нова школа” не турбувалася про те, щоб дати своїм учням міцні знання, просто акцент робився на ті знання, які були їм потрібні у майбутньому житті. "Нова" психологія виявилася сильним руйнатором застарілих догм традиційного мислення, активними діячами були О. Декролі [1], Е. Демолен [2], Г. Літц [5], А. Фер'єр [3], С. Френе [4] та інші.

У галузі розумового виховання "нові школи" прагнули розвивати розумові здібності особистості не шляхом накопичення знань, а шляхом розвитку дитячого мислення. Критичний розум формується через застосування наукового методу: спостереження, гіпотеза, перевірка, закон. Ряд обов'язкових предметів дають повну освіту, під якою розуміється не стільки енциклопедичне навчання, скільки надання дитині можливості розвивати всі свої природні задатки завдяки довкіллю та книгам.
За своїми навчальними програмами “нова школа” більш за все була подібною до реальних гімназій, хоча тут викладали і класичні мови латинську та грецьку. 3 огляду на те, що середня школа повинна давати дітям тільки загальну середню освіту, “нова школа” намагалася по можливості зберегти органічний зв'язок між окремими галузями наук для того, щоб дати дітям якомога ширший цілісний світогляд. Тому у “нових школах" не розбивали курс на велику кількість окремих предметів, а тільки ділили його на дві великі групи, які були двома дотичними ексцентричними колами. Одне із них охоплювало всю галузь людського життя, інше - життя природи. При викладанні педагоги намагалися зберегти єдність не тільки у межах кожної окремої групи, але зв' язати між собою і ці дві великі галузі знань, використовуючи найменшу нагоду, щоб підкреслити цей взаємозв'язок. Пов'язуючи мовознавство 3 історією, вона не розглядала останню тільки як матеріал для літературних вправ і не відводила вивченню мови тільки службову роль щодо історії, а вивчала їх як дві самостійні науки, які взаємно доповнювали одна одну.

Якщо традиційна школа вимагала від учнів насамперед фактичних знань, перевантажуючи їхню пам'ять великим обсягом матеріалу для вивчення, інколи занадто насиченою статистичними даними, то “нова школа" не переобтяжувала пам’яті своїх учнів. Виходячи 3 того, що тільки ті знання можуть бути міцними, які здобули самі учні, вона в основу навчання ставила практичні заняття, де учень під керівництвом учителя сам вчився спостерігати, вивчати, порівнювати, узагальнювати - одним словом, проходити самостійно процес, яким здобуваються знання. Підсилюючи таким чином інтерес до наукових досліджень, учень водночас непомітно для себе збагачував свою пам'ять великою кількістю фактичних даних, які він сам під керівництвом вчителя обробляв, зводив у систему і тому міцніше закріплював упам'яті. Цей поступовий, послідовний перехід від простого, близького та найбільш знайомого до більш складного та віддаленого проводився у “нових школах" систематично в усіх галузях знань.

Результатом такої системи навчання було не тільки досягнення ії головної мети - уміння учня самостійно мислити і самостійно продовжувати свої наукові дослідження, але й отримання ним такого багатого запасу міцних знань, який давав йомуможливість досягти успіхів у будь-якій галузі людської діяльності.

Для “нових шкіл” характерною була повна 


\section{ОРГАНІЗАЦІЯ НАВЧАННЯ ІНОЗЕМНОЇ ТА РІДНОЇ МОВИ У "НОВИХ ШКОЛАХ" ЗАХІДНОЄВРОПЕЙСЬКИХ КРАЇН}

відсутність бальної системи оцінювання та іспитів. У цьому не було потреби, адже педагогічний колектив шкіл знав своїх учнів дуже добре. Окрім того, щоденні практичні заняття служили постійною перевіркою знань учнів. Відсутність традиційної системи контролю та оцінювання знань не призводила до хаосу у навчальному та виховному процесі, адже батькам кожної чверті відсилалася детальна характеристика на їх дітей. У ній зазначалися найменші зміни, які відбулися 3 ними за останній семестр як в розумовому, так і фізичному та моральному відношенні. Методика навчання у“нових школах” була надзвичайно дієвою та ефективною. Використовуючи різноманітні методики у навчальному процесі, педагоги ставили перед собою декілька цілей. Зокрема, при вивченні рідної мови переслідувалися дві цілі: вивчення мови та розвиток в учнів художніх смаків. Для досягнення цієї мети в школі дуже багато уваги приділяли читанню художніх творів: “У нас література викладається не за підручниками і не за диктованими записами, - говорив доктор Літц, - учні самі не хочуть слухати критики таких речей, про які вони не читали. 3 літературою вони знайомляться читаючи або слухаючи твори письменників та розповіді про їх життя" $[5,101]$. У шкільних бібліотеках було багато різноманітної літератури, яка добиралася відповідно до вікових груп дітей. Щоб виховувати у дітях свідоме, вдумливе ставлення до книг, у новій школі дітей привчали визначати у кожній прочитаній книзі головні думки і складати короткий конспект ії змісту.

Після читання важливе місце на уроках рідної мови займало усне і письмове відтворення не тільки прочитаного, але й побаченого, почутого та пережитого дітьми. Для усної відповіді учень завжди викликався на кафедру, де він повинен був говорити, звертаючись прямо до класу. Поки він говорив, ніхто не мав права його переривати. Для письмових викладів вчителі намагалися добрати теми, які були особливо близькими для дітей і робота над якими приносила їм задоволення. У зв'язку з тим, що смаки у дітей були різними, їм пропонувалося для написання декілька тем на вибір. Хорошим засобом навчання мови для учнів “нових шкіл” було й обов'язкове ведення щоденника.

Щодо форми викладу власних думок, “нова школа” дотримувалася точки зору, що таємниця хорошого літературного стилю полягає в тому, щоб писати так, як говориш. Тому від дітей вимагалося якомога простішого, зрозумілішого та природнього викладення думок, не допускалося при цьому нічого вульгарного та граматично неправильного. Кожній письмовій роботі передував усний виклад та складання плану, весь матеріал групувався та класифікувався всім класом, а спільно вироблені основні пункти плану записувалися на дошці. Завдяки постійним вправам, що передбачали аналіз та синтезування фактів, явищ та ідей, приведення їх у струнку систему, вихованці поступово привчалися засвоювати кожен предмет, обробляти та систематизувати будь-який матеріал. Отже, уроки рідної мови допомагали решті предметів, адже були самі по собі хорошою школою тренування думки.

Що стосується граматики, то “нова школа" вбачала у ній не мету, а тільки засіб для вивчення мови і відводила їй рівно стільки часу, скільки було необхідно для знання мови. Граматикою учні ніколи не займалися окремо, а тільки принагідно при читанні та письмі. Граматичні правила дітям не давали готовими, учні самі мали виводити їх через практичне оволодіння мовою.

Свого часу французький педагог Рауль Фрері 3 цього приводу говорив: для того, щоб знати французьку мову, не потрібно її вивчати; достатньо чути, як нею розмовляють, і читати книги французьких авторів: “Можна подумати, що це благодіяння природи нам не до смаку, оскільки давалося нам занадто легко, і тому ми придумали собі спосіб заставити наших дітей купувати дорогою ціною те, що вони могли мати задарма. Ми придумали вивчати свою рідну мову так, як вивчаємо мертві мови. Ми покрили іï колючим дротом граматики та аналізів і вибудували навколо неї високі мури правил, хитромудрих тонкощів, які створені ніби зумисне для того, щоб відбити у них будь-яке бажання займатися рідною мовою. Можна сміливо сказати, що більше половини часу, який проводять у школі наші діти у початковій школі, приноситься у жертву тиранії орфографії. Ця наука умовностей пожирає дорогоцінний час їхнього життя. Я б хотів, щоб діти хоча б до тринадцяти років були позбавлені тортур граматики" [5, 104].

Рауль Фрері вважав, що орфографія може засвоюватися дітьми самостійно. Що стосується правил, то їх можна буде пояснити учням протягом декількох годин, коли вони вже настільки дозріють, щоб їх легко засвоїти. У свою чергу, Демолен також підтримував Рауля Фрері: найкращий метод для вивчення рідної мови полягає у тому, щоб читати якнайбільше художніх творів відомих авторів. Так засвоюється не тільки хороший стиль, але й орфографія та граматика. I якщо добір авторів буде добрим, то це буде найприємніший спосіб навчання для дітей. 


\section{ОРГАНІЗАЦІЯ НАВЧАННЯ ІНОЗЕМНОЇ ТА РІДНОЇ МОВИ У “НОВИХ ШКОЛАХ” ЗАХІДНОСВРОПЕЙСЬКИХ КРАЇН}

Особливу увагу педагоги “нових шкіл” при вивченні рідної мови звертали на розвиток художніх почуттів за допомогою літературних творів. Тут головним завданням було не порушити цілісності та глибини вражень, які були викликані прочитанням того чи іншого художнього твору. Тому вчителі намагалися уникнути критичного аналізу прочитаного тексту твору. I навпаки, із розумінням ставилися до викликаних у дітей настроїв унаслідок прочитання твору, вважаючи їх дорогоцінним джерелом натхнення та майбутньої творчості. Велику допомогу у реалізації цієї мети їм надавала музика та образотворче мистецтво. Знайомлячи дітей 3 кращими зразками геніальних творів літератури, вчитель утримувався від художньої критики, якщо вона не була викликана питаннями від дітей. Пропонуючи дітям поряд з кращими зразками літератури інколи і посередні твори, він пропонував їм самим робити висновки та порівняння. Художні твори давали досить багато матеріалу для письмових творчих робіт учнів, $\mathrm{i}$ дуже часто служили першим поштовхом до пробудження їхньої творчої уяви.

Іноземні мови у “нових школах" гармонійно вписувалися у зміст навчання. Як правило, вчителями іноземних мов тут працювали іноземці або люди, які провели за кордоном значну частину свого життя, тобто носії мови. При цьому вчителі іноземної мови говорили з дітьми тільки іноземною мовою чи то у класі, чи за його межами. Як тільки діти засвоювали невеликі фрази, вони починали писати маленькі твори на різні теми. Старші учні вели свої щоденники іноземними мовами. Час від часу вони також писали додому листи іноземними мовами. Інколи навіть Богослужіння у церкві проводилися різними мовами. Зубріння, вивчення напам'ять граматики тут не було. Хіба що учні виконували описи в різних часових формах. Ось як описував урок німецької мови в Аббатсхолмі один із керівників цієї школи: “За знаком вчителя хлопчики виходили вперед один за одним, і кожен повинен був виконувати якусь дію: чи то знімати чоботи, чи кланятися, при цьому він разом з усіма повинен був називати іноземною мовою кожну свою дію. Часто на допомогу приходила уява або якась картина, тоді клас перетворювався в басейн або їдальню, майстерню, готель, пральню, вагон, пошту і т.д. Дії, які відповідали кожному з цих місць, позначалися німецькою мовою. Так, для прикладу, учень починає майструвати ящик для інструментів і при цьому розповідає для всього класу: “Я беру дошку, приношу пилку, знімаю 3 полиці кутомір і масштаб, міряю довжину ящика i тощо” $[5,104]$. Діти при цьому ніколи не відчували труднощів у виборі матеріалу для розмови. Їх цікавив сам зміст розмови, і вони запам'ятовували багато слів, які могли їм знадобитися в чужій країні. До вивчення граматики діти приступали тільки тоді, коли навчилися трохи володіти практичною мовою. У старших класах у “нових школах” іноземними мовами викладалися такі дисципліни, як історія, географія та література відповідних країн.

На думку педагогів, які працювали у “нових школах", кращий спосіб навчитися будь-якої мови - чужої або рідної - це говорити нею якомога більше. Тому навчання іноземних мов організовувалося виходячи саме із цього принципу. При цьому тут ніколи не вдавалися до зубріння такого курсу, як "Практична граматика". Відомий прихильник нових шкіл доктор Літц, який тривалий час викладав в Абатсхолмі історію Німеччини німецькою мовою, згадує свої уроки: “У класі п’ятнадцятирічних ми вивішували на стіні декілька карт, які показували політичний поділ Свропи у різні часи, тут же висіла картина “Битва готів при Везувії'. Учитель - німець тут, у чужій країні дає урок з історії Німеччини. Місцевою мовою він при всьому бажанні цього б не зміг зробити тривалий час, хоча він за фахом i філолог, вивчав латину і греку, єврейську мову, готську та англосаксонську.

Якщо вже глухонімі за допомогою рухів та картин можуть спілкуватися між собою, то наскільки успішно може відбуватися обмін думками між носіями різних мов. Історичний зміст уроків так привернув увагу учнів, що вони, завдяки пробудженому в них інтересу, легко та швидко долали граматичні та стилістичні труднощі” $[5,104]$.

Таким чином, поєднуючи у навчальному процесі різні дисципліни, у “нових школах" намагалися отримати відразу декількох переваг одночасно: вивчити іноземну мову та засвоїти предмет, на якому відбувалося вивчення цієї мови. Такий метод у “нових школах” часто практикували і при вивченні природничих наук. При цьому учні майже забули, що вони вчаться іноземної мови. Тому почуття невдоволеності, яке майже завжди пробуджується в дітей, коли вони мають справу тільки 3 формою, тут зовсім відсутнє. Діти без бажання вивчали німецькі чи французькі слова або правила, але із задоволенням слухали і розповідали про Карла Великого, Наполеона і т.д. А те, що це може відбувалося тільки іноземною мовою, здавалося їм уже зрозумілим і природнім. Крім уже описаних методів навчання іноземних мов у “нових школах”, тут практикувався ще один, можливо, найбільш ефективний. Особливо активно він використовувався 


\section{ОРГАНІЗАЦІЯ НАВЧАННЯ ІНОЗЕМНОЇ ТА РІДНОЇ МОВИ У “НОВИХ ШКОЛАХ" ЗАХІДНОСВРОПЕЙСЬКИХ КРАЇН}

школами Демолена. Ці школи знаходили собі партнерів-однодумців із шкіл аналогічного типу в Англії та Німеччині. Згідно з існуючими домовленостями, між цими школами відбувався обмін учнів, які проживали у сім'ях шкіл партнерів. Опинившись в англомовному або німецькомовному середовищі, діти дуже швидко засвоювали іноземну мову та хорошу вимову, одночасно знайомлячись із життям та духом нації, мову якої вони вивчали. Все це діти могли зробити не вибиваючись із звичайної для них колії навчального процесу, адже вони могли продовжити те, що робили у своїй школі, в іншій подібній школі, тільки за кордоном та іншою мовою, але за тими ж програмами та методами. Витрати, пов'язані із переїздом в іншу школу за кордон, переважно брали на себе самі школи.

На відміну від французьких шкіл, англійські та німецькі школи не так часто користувалися цими методами. Хоча вони практикували також подорожі в інші країни для ознайомлення 3 культурою, традиціями та звичаями, але це було тільки у період шкільних канікул. Такі подорожі приносили багато користі дітям, адже знайомство iз країною, мову якої вони вивчали, допомагало їм краще їі засвоїти, зрозуміти національні особливості як сусідніх народів, так і власної нації.

Класичні мови - грецька та латинська - у всіх нових школах не вважалися обов'язковим предметом для вивчення, але пропонувалися тим, хто виявив бажання та інтерес до них у трьох старших класах. Хоча класичні мови тут вивчали тільки $2-3$ роки, учні і за цей період добивалися більших успіхів, ніж у класичних гімназіях, де термін навчання становив $7-8$ років.

При вивченні класичних мов практикувалися майже такі самі методи, як і при вивченні нових мов: якомога більше говорити і читати. Зважаючи на те, що говорити класичними мовами дуже важко, а також через брак класичних філологів, у “нових школах” вирішили, що діти повинні багато читати. Починати з малої кількості сторінок у день і поступово їх збільшувати. При цьому таке читання вважалося доцільним тільки за умови наявності напроти тексту оригіналу його перекладу. Саме переклад повинен був передавати учневі зміст кожного слова та речення, не примушуючи його довго та часто шукати потрібне слово у словниках.

На думку педагогів “нових шкіл”, дати учням готовий переклад - це значить дати їм такі ж засоби, якими користуються всі вчителі. Чим більше учень буде мати у своєму розпорядженні слів та зворотів, тим легше йому буде вивчити мову. Вивчення ж граматики: відмінювання дієслів, дієвідміни тощо, - не було необхідним для знання мови. Виходячи з цього, учня необхідно було позбавити зайвої трати часу та сил при вивченні напам'ять великого обсягу матеріалу, який він не в змозі засвоїти.

У “новій школі” в Абатсхолмі робилися спроби вдосконалити методику навчання класичних мов, як це було із новими мовами. “ Ви тут не побачите підручників, перенасичених великою кількістю строкатих фраз про перемоги Мільтіада, про могилу Сціпіона і т.д., які переносять дітей протягом п'ять хвилин без усякої системи у всі куточки земної кулі, в різні історичні періоди. Замість того, щоб тратити стільки сил на незв'язне, а тому безглузде учіння, діти і тут повинні вивчати класичні мови на якомусь цікавому для них шкільному предметі" [5, 104]. У початківців саме життя слугувало матеріалом для вправ. За допомогою вчителя вони вчилися складати маленькі фрази, називати предмети, які їх оточують, та описувати свої дії, вести коротенькі живі розмови. Старші за допомогою латинської мови вже вивчали римську історію, римську культуру. У старших класах навчання класичних мов мало на меті ознайомлення 3 пам' ятками Римської імперії, усе решта, на думку теоретиків “нового виховання”, повинні вивчати в університетах.

Висновки. Виявлено, що за своїми навчальними програмами “нові школи” були досить близькими до реальних гімназій. 3 огляду на те, що середня школа повинна була давати дітям середню освіту, у “нових школах" намагалися зберегти органічний зв'язок між окремими галузями наук. При вивченні рідної мови переслідувалися дві цілі: вивчення мови та розвиток в учнів художніх смаків. Для досягнення цієї мети в школі дуже багато уваги приділяли читанню художніх творів. Після читання важливе місце на уроках рідної мови займало усне і письмове відтворення не тільки прочитаного, але й побаченого, почутого та пережитого дітьми. Для письмових викладів вчителі намагалися добрати теми, які були особливо близькими для дітей i робота над якими приносила їм задоволення. Хорошим засобом навчання мови для учнів “нових шкіл” було й обов”язкове ведення щоденника. Граматичні правила дітям не давали готовими, учні самі мали виводити їх через практичне оволодіння мовою. Вчителями іноземних мов тут працювали іноземці або люди, які провели за кордоном значну частину свого життя, тобто носії мови. Вчителі іноземної мови говорили 3 дітьми тільки іноземною мовою чи то у класі, чи за його межами. Як тільки діти засвоювали невеликі фрази, вони починали писати маленькі твори на різні теми. Старші учні 


\section{ОРГАНІЗАЦІЯ НАВЧАННЯ ІНОЗЕМНОЇ ТА РІДНОЇ МОВИ У “НОВИХ ШКОЛАХ" ЗАХІДНОЄВРОПЕЙСЬКИХ КРАЇН}

вели свої щоденники іноземними мовами. Зубріння, вивчення напам'ять граматики тут не було. Використовувався обмін учнів, які проживали у сім'ях країни, мова якої вивчалася.

Доведено, що метою “нових шкіл” було виховання всебічно розвиненої ініціативної особистості, яка б уміла практично використовувати здобуті знання та самостійно приймати рішення. У зв'язку із цим у “нових школах" прагнули впроваджувати такі форми організації навчання, які б максимально активізували навчальну діяльність самих учнів. Навчальному процесу були притаманні тенденції піднесення індивідуальності, самостійності, свободи; зведення навчального процесу до спонтанної, некерованої школою та вчителем активності дитини, зосередження педагога на інтересах дитини, iіi індивідуальних потребах; створення умов для природного розвитку дитини; для свободи і доброго самопочуття у школі (школа для учня); для запобігання психічного та фізичного перевантаження учня; зміщення акцентів у професійній діяльності вчителя із суго навчальної функції на функцію партнерства, опікунства, наставництва, інспірації; підготовка вихованців до активного життя у суспільстві, побудованому на засадах демократії, свободи і справедливості.

\section{ЛІТЕРАТУРА}

1. Decroly O. L'école active par la méthode Decroly / O.Decroly. - Bruxelles: Mamertin, 1930.$65 \mathrm{p}$.
2. Demolins E. L'education nouvelle. L'ecole des Roches / E. Demolins. - Paris, 1898. - 134 p.

3. Ferrier A. L'école Active / A. Ferrier. - Genève. $-1922-$ T.2. -380 p.

4. Freinet C. Naissance d'une pédagogie populaire. - Historique de la CEL / C. Freinet. - Cennes, 1949. $-125 \mathrm{p}$.

5. Lietz Hermann "Emlohstobba. Roman oder Wirklichkeit. Bilder aus dem Schulleben der Verganngenheit, Gegenwart oder Zukunft" / Herman Lietz. - Berlin, 1897. - $170 \mathrm{~s}$.

\section{REFERENCES}

1. Decroly, O. (1930). L'école active par la méthode Decroly [Active Schools according to Dercoly's Methods]. Bruxelles: Mamertin, 65 p. [in French].

2. Demolins, E. (1898). L'education nouvelle. L'ecole des Roches [New Education in Roch School]. Paris, 134 p. [in French].

3. Ferrier, A. (1922). L'école Active [Active School]. Genève,vol.2, 380p. [in French].

4. Freinet, C. (1949). Naissance d'une pédagogie populaire [The Birth of Popular Education]. Historique de la CEL. Cennes, 125 p. [in French].

5. Lietz Hermann (1897). "Emlohstobba. Roman oder Wirklichkeit. Bilder aus dem Schulleben der Verganngenheit, Gegenwart oder Zukunft" ["Emlohstobba. Fiction or Reality. Episodes from Verganngenheit School Life, Present or Future"]. Berlin, 170 p. [in German].

Стаття надійшла до редакції 12.02.2018

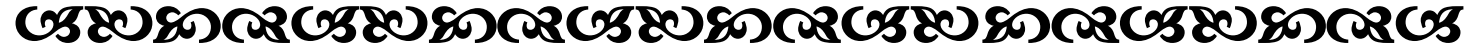

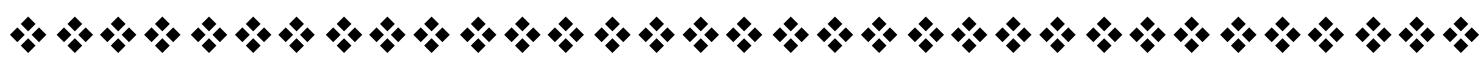 \\ “...наші знання ніколи не можуть мати қіния саме тому, що предмет пізнання нескінченний”.}

Блез Ласкаль

французький білособ, письменник

“Навчання ніколи не вичерпує розум".

Леонардо да Вінчі видатний італійський вчений, дослідник, винахідник $і$ художник

“Слово - то мудрості промінь, слово - то думка людська".

Олена Tиілқа

украйнська письменниия, публіиист, етнограбб

\section{$\% * \% * \%$

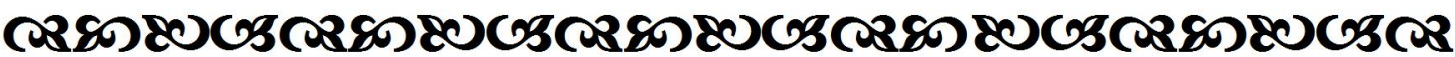

